\title{
Prinsip Syariah Dalam Penyelenggaraan Bank Wakaf Mikro Sebagai Perlindungan Hak Spiritual Nasabah
}

\author{
Zeehan Fuad Attamimi \\ Fakultas Hukum Universitas Diponegoro, Semarang \\ zeehanfuadatt25@gmail.com \\ Hari Sutra Disemadi \\ Fakultas Hukum Universitas Diponegoro, Semarang \\ haridisemadi@gmail.com

\section{Budi Santoso} \\ Fakultas Hukum Universitas Diponegoro, Semarang \\ budisantoso@gmail.com
}

DOI: $10.2391 /$ jjr.v9i2.8897

\begin{abstract}
Submission
Track:

\section{ABSTRAK}

Received:

Tujuan :Penelitian ini bertujuan untuk mengetahui pengaturan

25 September 2019 mengenai prinsip syariah dalam pengelolaan Bank Wakaf Mikro

25 Septentor 2019 (BWM) sebagai upaya perlindungan hak spiritual nasabah atau masyarakat pada umumnya.
\end{abstract}

Final Revision:

13 Desember 2019

Metodologi:Penelitian ini adalah metode yuridis normatif atau metode penelitian hukum yang bersifat doctrinal,dengan menggunakan pendekatan perundang-undangan dan pendekatan konseptual.

Available online:

Temuan:Penelitian ini menunjukan dasar hukum penyelenggaraan $B W M$ di Indonesia sebagai bagian dari LKM diatur dalam UU

17 Januari 2020

Corresponding

Author: LKM. UU LKM ini mewajibkan penerapan prinsip syariah dalam pengelolaan bisnis BWM. Kebijakan penerapan prinsip syariah ini dimaksudkan sebagai jaminan perlindungan hak spiritual masyarakat khususnya nasabah dari BWM yang mayoritas beragama Islam.

Hari Sutra Disemadi haridisemadi@gmail.com

Kegunaan:Kebijakan hadirnya bisnis BWM pada dasarnya untuk memberikan pilihan bagi masyarakat, khususnya umat Islam dalam memilih lembaga keuangan yang menyediakan jasa keuangan 
seperti pembiayaan.Sedangkan hasil dari penelitian ini diharapkan dapat mengghilangkan sikap "skeptis" masyarakat terhadap lembaga keuangan berbasis Hukum Islam yang masih dianggap sama dengan lembaga keuangan konvensional lainnya.

Kebaruan/Orisinalitas:Berbeda dengan penelitian yang telah dilakukan sebelumnya, penelitian ini lebih berfokus pada kebijakan prinsip syariah pada BWM sebagai upaya perlindungan hak spiritual.

Keywords: Prinsip Syariah, Bank Wakaf Mikro, Hak Spiritual

\section{PENDAHULUAN}

Dewasa ini, di Indonesia perkembangan sistem ekonomi syariah bisa dikatakan sangatlah signifikan. Hal ini tentunya menjadi kabar gembira bagi pelaku ekonomi syariah. Mengingat, saat ini pertumbuhan bisnis syariah secara subtantif sudah memulai mendapatkan perhatian khusus dari masyarakat.1 Pertumbuhan ini secara nyata dapat dilihat dari berbagai jenis lembaga keuangan yang berlabel syariah atau Islam.2 Hadirnya perbankan syariah, koperasi syariah, asuransi syariah sampai pada saat ini dengan hadirnya Bank Wakaf Mikro setidaknya dapat dijadikan sebagai indikator perkembagan serta pertumbuhan lembaga keuangan syariah di Indonesia. 3

Meskipun lembaga keuangan yang berlabelkan syariah eksistensinya telah menjamur di Indonesia, namun terdapat sebagian masyarakat yang berasumsi bahwasanya lembaga keuangan berbasis syariah tersebut hanyalah sebuah label yang dipergunakan agar dapat menarik simpati masyarakat Indonesia yang mayoritas beragama Islam.4 Masih banyak masyarakat yang berasumsi bahwa lembaga keuangan syariah merupakan lembaga keuangan konvensional dengan mempergunakan istilah-istilah Islam, dengan bagian akad atau perjanjian yang dibubuhi kalimat Bismillahirrahmaanirrahiim serta para pegawai yang mengenakan pakaian muslim dan mengucap salam, akan tetapi masyarakat masih berpendapat

\footnotetext{
1 Muhamad Mustaqim. "Prinsip Syariah Dalam Manajemen Sumber Daya Manusia (Studi Atas Implementasi Manajemen Sumber Daya Manusia UMKM di Kudus)." Jurnal Penelitian, 10(2), 399-422, (2016), h. 400

2 Andri Soemitra, Bank Dan Lembaga Keuangan Syariah, (Jakarta: Prenadamedia Group, 2018), h. 121

3 Muhamad Mustaqim. Ibid., h. 401

4 Wardah Yuspin. "Penerapan Prinsip Syariah dalam Pelaksanaan Akad Murabahah.” Publikasi Ilmiah, 10(1), $55-67,(2007)$, h. 56
} 
bahwa dalam pelaksanaan akad atau perjanjian lembaga keuangan syariah masih menggunakan cara-cara yang dilarang oleh Agama Islam.

Pandangan sinis oleh beberapaka kalangan umat Islam itu sendiri dapat dilihat dari rendahnya kepercayaan masyarakat Indonesia terhadap lembaga keuangan perbankan yang berbasis syariah. Akibatnya, dapat terlihat kurangnya partisipasi umat Islam dalam investasi atau perguliran modal terhadap lembaga keuangan syariah.5

Hal di atas tersebut merupakan bentuk skeptis dari masyarakat terkait lembaga keuangan syariah karena memang tidak dapat dipungkiri bahwasanya konotasi lembaga keuangan khususnya perbankan sejak dahulu memang terpisah secara nyata dengan syariah, pada akhirnya pembentukan lembaga keuangan sayariah masih banyak yang tidak percaya akan adanya keberhasilan para ahli ekonom syariah dalam menyatukan lembaga keuangan dengan syariah itu sendiri.6

Pada sisi lain, perkembangan lembaga keuangan syariah ini tentu saja menjadi sebuah harapan yang bisa kita angankan dalam pengembagan perekonomian Islam. Perkembagan lembaga keuangan syariah ini tentu saja perlu diapreasiasi sebagi sesuatu hal yang positif. Walaupun terkadang lembaga keuangan syariah hanya menonjolkan simbol dan label belaka, hal inilah yang menjadi tantangan kita bersama bagaimana agar lembaga keuangan syariah mempunyai integritas dan spirit dalam kegiataan perekonomian Islam.7

Salah satu lembaga keuangan syariah saat ini yang telah mengalami pertumbuhan adalah Bank Wakaf Mikro (BWM). Program BWM diluncurkan sejak Oktober 2007 yang dimaksudkan sebagai solusi penyedia akses permodalan atau pembiayaan bagi masyarakat kurang mampu di sekitar wilayah pesantren.8 Hingga Juli 2019, terdapat 52 BWM yang tersebar di Indonesia dengan nilai total pembiayaan Rp. 24, 9 miliar untuk 19.543 nasabah yang terdiri dari 2.347 kelompok usaha masyarakat sekitar pesantren Indonesia (Kumpi). Hadinya BWM merupakan salah satu trobosan kebijakan yang dilakukan oleh Otoritas Jasa Keuangan $(\mathrm{OJK})$ guna menghadirkan layanan keuangan yang tumbuh berkelanjutan untuk mewujudkan kesejahteraan rakyat diseluruh wilayah Nusantara.

\footnotetext{
5 Amir Mu'allim. "Persepsi Masyarakat terhadap Lembaga Keuangan Syariah.” Al-Mawarid Journal of Islamic Law Edisis 10, 17-31, (2003), h. 18

6 Wardah Yuspin. Ibid., h. 57

7 Muhamad Mustaqim. Ibid., h. 401

8 Otoritas Jasa Keuangan, Siaran Pers OJK Keluarkan Izin 41 Bank Wakaf Mikro, www.ojk.go.id Diakases Pada Tanggal 2 September 2019
} 
BWM merupakan bagian dari Lembaga Keuangan Mikro yang menerapkan prinsip syraiah dalam penyelenggaraannya. Penyelenggaraan BWM di Indonesia di atur dalam Undang-Undang Nomor 1 Tahun 2003 tentang Lembaga Keuangan Mikro serta Peraturan Otoritas Jasa Keuangan (POJK) Nomor 62/POJK.05/2015 tentang Perubahan atas POJK Nomor 13/POJK.05/2014 tentang Penyelenggaraan Usaha Lembaga Keuangan Mikro. Walapun telah disebutkan di atas, bahwa BWM merupakan lembaga keuangan yang menerapkan prinsip syariah, 9 tetap saja masih ada sebagian masyarakat yang berasumsi bahwa BWM dalam pengoprasiannya masih sama dengan lembaga keuangan konvensional lainnya kuhusunya perbankan. Di tambah lagi penggunaan kata "Bank" pada "Bank Wakaf Mikro" memperkuat asumsi masyarakat bahwa penyelenggaraan BWM di Indonesia sama halnya dengan penyelenggaraan lembaga keuangan konvensional lainnya.10 Dengan kata lain, dapat dipertanyakan apakah pengaturan penyelenggaraan BWM yang nota bene bertujuan untuk menjamin hak spiritual masyarakat telah dimuat secara tegas ataukah hanya penggantian istilah belaka?.

Terlepas dari masih kurangnnya kesadaran dan kepercayaan masyarakat terhadap lembaga keuangan Islam khususnya BWM di Indonesia, maka dari itu penelitian normatif ini akan membahas mengenai prinsip-prinsip syariah apa saja yang digunakan dalam penyelenggaraan Bank Wakaf Mikro di Indonesia sebagai bentuk upaya pelindungan hak spiritual masyarakat. Penelitian ini dimaksudkan untuk memberi pemahaman yang lebih mengenai BWM sebagai lembaga keuangan mikro syariah, yang tidak sekedar hanya label untuk menarik simpati masyarakat muslim.

Penelitian sebelumnya yang terkait dengan penelitian ini adalah penelitian yang dilakukan oleh Wardah Yuspin pada tahun 2007, penelitian ini berfokus pada implementasi prinsip syariah dalam pelaksanaan Akad Murabahah. Penelitian oleh Ro'fah Setyowati, Lastuti Abubakar dan Nunung Rodliah pada tahun 2017, penelitian ini berfokus pada perlindungan hak spiritual dalam membangun keredibilitas industri perbankan Islam. Kemuadian penelitian oleh Ro'fah Setyowati, Indah Purbasari dan Muhammad Fauzan pada tahun 2018, fokus penelitian ini berfokus pada penyelesaian sengketa perbankan syariah dalam melindungi hak spiritual konsumen. Berbeda dengan penelitian sebelumnnya,

\footnotetext{
9 Hari Sutra Disemadi \& Budi Santoso. "Pelaksanaan Fungsi Pembinaan Dan Pengawasan Otoritas Jasa Keuangan Terhadap Lembaga Keuangan Mikro Syariah Di Jawa Tengah (Studi Pada Bank Wakaf Mikro Sunan Gunung Jati Ba'alwy)", Tesis: Fakultas Hukum Universitas Diponegoro, (2019), h. 4 10 Amir Mu'allim. Op.Cit., h. 18
} 
penelitian kali ini lebih berfokus pada kebijakan mengenai prinsip syariah dalam penyelenggaraan BWM sebagai bagian dari upaya perlindungan nasabah.

\section{METODOLOGI PENELITIAN}

Penelitian ini merupakan penelitian doctrinal atau penelitian yuridis normatif. Pada penelitian doctrinal ini, penulis menggunakan pendekatan normatif atau peraturan perundangundangan dan pendekatan konseptual.11 Pendekatan normatif merupakan pendekatan yang mengacu pada ketentuan peraturan perundang-undangan serta Hukum Islam, sedangkan pendekatan konseptual merupakan pendekatan yang digunakan untuk memahami terkait teori, konsep-konsep yang dapat dijadikan landasan dari penelitian saat ini. Data yang digunakan pada penelitian yang berjudul "Prinsip Syariah Dalam Penyelenggaraan Bank Wakaf Mikro Sebagai Perlindungan Hak Spiritual Nasabah" kali ini adalah data sekunder.

Data sekunder merupakan data yang diperoleh tidak secara lansung dari lapangan. Data sekunder ini terbagi atas bahan hukum primer, bahan hukum sekunder, dan bahan hukum tersier. Bahan hukum primer adalah bahan hukum/data yang sifatnya mengikat seperti UU tentang LKM, POJK, bahan Hukum Islam, dan bahan hukum primer lainnya yang memiliki keterkaitan dengan penelitian ini. Bahan hukum sekunder adalah bahan hukum yang sifatnay memberikan kejelasan terhadap bahan hukum primer, contoh bahan hukum sekunder adalah buku-buku, jurnal-jurnal, ataupun hasil penelitian terdahulu. Sedangkan bahan hukum tersier adalah bahan hukum/data tambahan yang lebih memperjelas bahan hukum primer dan bahan hukum sekunder, contoh bahan hukum tersier adalah kamus-kamus serta media online.

Data sekunder di atas diperoleh melalui teknik pengumpulan studi kepustakaan atau library research. Teknik pengumpulan data ini dimaksudkan agar dapat membantu penulis nantinya untuk memilah dan mengelompokan data-data kedalam jenis bahan-bahan hukum yang sudah ada.12Pengelompokan data sekunder ini bertujuan untuk memudahkan penulis dalam menganalisis data. Analisis data pada penelitian ini adalah analisis kualitatif, yaitu prosedur analisis komprehensif yang bertujuan menghasilkan data deskriptif berupa kata-kata atau kalimat tertulis dan nantinya dapat membantu penulis menjawab permasalahan serta membuat kesimpulan yang benar.

\footnotetext{
11 Suteki \& Galang Taufani. Metodologi Penelitian Hukum (Filsafat, Teori Dan Praktik), (Depok: PT RajaGrafindo Persada, 2018), h. 148

12 Zainuddin Ali. Metode Penelitian Hukum, (Jakarta: Sinar Grafika, 2018), h. 2
} 


\section{PEMBAHASAN}

\section{Pengaturan Penyelenggaraan Bank Wakaf Mikro (BWM) Di Indonesia}

Bank Wakaf Mikro (BWM) adalah bagian dari Lembaga Keuangan Mikro (LKM) yang menerapkan prinsip syariah, dibentuk atas dasar semangat Pasal 27 Ayat (2)13 serta Pasal 33 ayat (1)14 dan ayat (4)15 Undang-Undang Dasar 1945. Keberadaan BWM pada prinsipnya adalah lembaga keuangan yang menyediakan jasa pembiayaan berskala mikro, kepada kelompok usaha masyarakat sekitar pesantren Indonesia (Kumpi), memperluas lapangan pekerjaan, dan dapat berperan sebagai instrumen pemerataan dan peningkatan pendapatan masyarakat, serta meningkatkan kesejahteraan masyarakat yang berpenghasilan rendah. 16

Berdasarkan hal di atas, agar dapat memenuhi kebutuhan layanan keuangan terhadap masyarakat yang berpenghasilan rendah (miskin), disusunlah Undang-Undang Nomor 1 Tahun 2013 tentang Lembaga Keuangan Mikro (untuk selanjutnya disebut UU LKM) yang diundangkan pada tanggal 8 Januari 2013. UU LKM dimaksudkan untuk memberikan landasan hukum serta kepastian hukum kerhadap kegiatan LKM termasuk penyelenggaraan BWM.

Berdasarkan pengertian LKM yang disebutkan dalam Pasal 1 Angka 1 UU LKM17 bahwasanya penyelenggaraan LKM termasuk di dalamnya adalah BWM tidak semata-mata mencari keuntungan melainkan bertujuan untuk pemberdayaan masyarakat berpenghasilan rendah. Hal ini selaras dengan tujuan penyusunan UU LKM yaitu: 1). Untuk mempermudah akses masyarakat berpenghasilan rendah (miskin) untuk memperoleh pembiayaan/pinjaman skala mikro; 2). Untuk memberdayakan ekonomi dan produktifitas masyarakat berpenghasilan rendah (miskin); dan, 3). Untuk meningkatkan pendapatan serta kesejahteraan masyarakat berpenghasilan rendah (miskin).

Penyaluran pembiayaan ataupun pinjaman dan pengelolaan simpanan oleh LKM menurut Pasal 12 Ayar (1) UU LKM dapat dilaksanakan secara konvesional maupun

\footnotetext{
13 Pasal ini menyebutkan "Tiap-tiap warga negara berhak atas pekerjaan dan penghidupan yang layak bagi kemanusiaan".

14 Pasal ini menyebutkan "Perekonomian disusun sebagai usaha bersama berdasarkan atas asas kekeluargaan".

15 Pasal ini menyebutkan "Perekonomian nasional diselenggarakan berdasarkan atas demokrasi ekonomi dengan prinsip kebersamaan, efisiensi berkeadilan, berkelanjutan, berwawasan lingkungan, kemandirian, serta dengan menjaga keseimbangan kemajuan dan kesatuan ekonomi nasional".

16 Hari Sutra Disemadi \& Raden Ani Eko Wahyuni. "Eksistensi Dan Kebijakan Regulasi Perizinan Lembaga Keuangan Mikro Oleh Otoritas Jasa Keuangan”, Yustisiabel, 3(2), 106-117, (2019), h. 109

17 Pasal ini menyebutkan "Lembaga Keuangan Mikro yang selanjutnya disebut LKM adalah lembaga keuangan yang khusus didirikan untuk memberikan jasa pengembangan usaha dan pemberdayaan masyarakat, baik melalui pinjaman atau pembiayaan dalam usaha skala mikro kepada anggota dan masyarakat, pengelolaan simpanan, maupun pemberian jasa konsultasi pengembangan usaha yang tidak semata-mata mencari keuntungan".
} 
berdasarkan hukum Islam atau prinsip syariah. Atas ketentuan tersebut dapat dikatakan bahwa BWM merupakan LKM yang pelaksanaannya berdasarkan prinsip syariah dan dalam kegiatan usahannya menurut Pasal 12 Ayat (2) UU LKM, penyelenggaraan BWM wajib dilaksanakan sesuai dengan fatwa-fatwa syariah yang dikeluarkan oleh DSN-MUI (Dewan Syariah Nasional-Majelis Ulama Indonesia).

BWM sendiri adalah sebuah lembaga keuangan yang berfokus pada pembiayann masyrakat kurang mampu, dan dalam hal ini, skema permodalan dari BWM terbilang unik. Setiap BWM akan menerima Rp. 3 miliar-Rp. 4 miliar yang berasal dari semua kalangan donatur baik perusahaan maupun perorangan. Dana yang diterima oleh BWM tidak akan disalurkan semuanya menjadi pembiayaan melainkan sebagian akan disimpan dalam bentuk deposito di Bank umum syariah.18

Kebijakan pengaturan mengenai penyelenggaraan BWM selain diatur dalm UU LKM, diatur juga dalam Peraturan Otoritas Jasa Keuangan (POJK) No. 62/POJK.05/2015 Tentang Perubahan Atas POJK No. 13/POJK.05/2014 Tentang Penyelenggaraan Usaha Lembaga Keuangan Mikro. Pasal 2 POJK ini menyiratkan bahwa BWM dalam menjalankan kegiatan usahanya hanya melalui penyaluran pembiayaan skala mikro berdasarkan prinsip syariah. BWM dalam menyalurkan pembiayaan wajib melakukan analisis atas kelayakan penyaluran pembiayaan dengan tujuan pengembangan usaha dan pemberdayaan anggota dan masyarakat seperti yang disebutkan pada Pasal 3 POJK ini.

Pasal 4 POJK No. 62/POJK.05/2015 mengatur bahwa BWM wajib menetapkan imbal hasil maksimum pembiayaan yang akan diterapkan dalam menjalankan kegiatan usahanya, di mana BWM wajib melaporkan imbal hasil maksimum ini kepada OJK setiap empat (4) bulan pada bulan April, Agustus, dan bulan Desember. Apabila BWM bermaksud menaikan imbal hasil maksimum pembiayaan, BWM wajib terlebih dahulu melaporkannya kepada OJK serta mengumumkannya melalui surat kabar harian lokal atau papan pengumumam di kantor BWM itu sendiri agar dapat mudah diketahui oleh masyarakat.

Pelaksanakan pembiayaan yang dilayani oleh BWM dibatasi sebesar Rp. 50.000, dan BWM dilarang menolak batas pembiayaan terendah tersebut, hal ini telah di atur dalam Pasal 5 POJK No. 62/POJK.05/2015. Kemudian Pasal 7 POJK ini menyuratkan bahwasanya BWM

18 Otoritas Jasa Keuangan, Mewujudkan Kesejahteraan Masyarakat Dengan Bank Wakaf Mikro,www.sikapiuangmu.ojk.go.id Diakses Pada Tanggal 15 September 2019 
wajib memenuhi batas maksimum pemberian pembiayaan kepada anggota dan masyarakat dengan rincian paling tinggi 10\% dari modal BWM untuk nasabah kelompok dan paling tinggi 5\% dari modal BWM untuk nasabah perseorangan.

Penyelenggaraan penyaluran pembiayaan oleh BWM, wajib ditetapkan menjadi tiga (3) kelompok, seperti yang telah disebutkan oleh Pasal 8 POJK No. 62/POJK.05/2015. Tiga kelompok yang disebutkan dalam pasal ini adalah lancar, diragukan, dan macet. Kemudian terkait kualitas pembiayaan tersebut BWM wajib membentuk penyisihan pembiayaan paling sedikit $0 \%$ dari pembiayaan dengan kualitas lancar, 50\% dari pembiayaan dengan kualits diragukan, dan 100\% dari pembiayaan dengan kualitas macet.

Atas penjelasan kewajiban yang harus dilaksanakan oleh BWM dalam penyelenggaraan kegiatan usahannya, POJK No. 62/POJK.05/2015 juga mengatur mengenai larangan yang tidak boleh dilaksanakan oleh BWM. Pasal 8 POJK ini menyebutkan larangan tersebut sebagai berikut:

1) BWM dilarang menerima simpanan berupa giro dan ikut serta dalam lalu lintas pembayaran;

2) BWM dilarang melakukan kegiatan usaha dalam valuta asing;

3) BWM dilarang melakukan usaha perasuransian sebagai penanngung;

4) BWM dilarang bertindak sebagai penjamin;

5) BWM dilarang memberi pembiayaan kepada BWM lain kecuali dalam rangka mengatasi kesulitan likuiditas bagi BWM tersebut dalam wilayah kabupaten/kota yang sama;

6) BWM dialarang melakukan penyaluran pembiayaan di luar cakupn wilayah usaha; dan/atau

7) BWM dilarang melakukan usaha di luar kegiatan pembiayaan dalam usaha mikro demi pengembangan usaha dan pemberdayaan anggota dan masyarakat.

Berdasarkan penjelasan di atas, maka dapat dikatakan bahwa POJK No. 62/POJK.05/2015 ini dibentuk berdasarkan amanat UU LKM yang menyebutkan OJK sebagai otoritas keuangan satu-satunya di Indonesia wajib membina, mangatur dan, mengawasi LKM. Sehingga dibentuklah POJK mengenai penyelenggaraan kegiatan usaha LKM. POJK ini diharapkan mampu menjadikan BWM dapat terus berkontribusi dalam memberdayakan anggota dan masyarakat berpenghasilan rendah sebagai pelaku usaha mikro. 


\section{Prinsip Syariah Bank Wakaf Mikro Sebagai Upaya Perlindungan Hak Spiritual Nasabah}

Bank Wakaf Mikro adalah salah satu Lembaga Keuangan Mikro (LKM) yang dalam operasionalnya sesuai prinsip syariah.19 Implementasi prinsip syariah merupakan pembeda utama antara BWM dengan LKM konvensional lainnya. Prinsip syariah tersebut mengacu pada Hukum Islam yang berpedoman kepada Al-Qur'an dan Hadist.2oIslam itu sendiri adalah agama yang memiliki konsep pengaturan terhadap kehidupan manusia secara konprehensif serta universal baik dalam hubungan dengan Tuhan (HabluminAllah) ataupun hubungan sesame manusia (Hablumminannas).21

Tiga (3) pilar utama dalam ajaran Agama Islam adalah Aqidah, Syariah, dan Akhlaq yang akan dijabarkan sebagai berikut:22 (1). Aqidah merupakan komponen atau bagian ajaran Agama Islam yang mengatur tentang keyakinan terhadap kekuasaan adan keberadaan Allah SWT., sehingga harus menjadi keimanan seseorang yang beragama Islam manakala melakukan bermacam aktivitas di dunia semata-mata untuk mendapakan keridhaan Allah SWT., sebagai khalifah yang mendapat amanah dari Allah SWT; (2). Syariah adalah komponen atau bagian ajaran Agama Islam yang mengatur mengenai kehidupan manusia yang beragama Islam baik dalam bidang ibadah (HabluminAllah) maupun dalam bidang muamalah antar sesama manusia (Hablumminannas)yang merupakan aktualisasi dari aqidah yang menjadi kepercayaan atau keyakinannya. Muamalah sendiri meliputi hal yang menyangkut ekonomi atau harta benda dan perniagaan yang bisa disebut dengan (Muamalah Maliyah); dan (3). Akhlaq adalah komponen ajaran Agama Islam yang berisikan landasan prilaku serta kepribadian yang nantinya akan mencirikan dirinya sebagai seorang muslim taat berdasarkan syariah dan aqidah yang menjadi pedoman atau panduan hidupnya sehingga memiliki akhlaqul karimah.

\footnotetext{
19 Hari Sutra Disemadi \& Kholis Roisah. "Kebijakan Model Bisnis Bank Wakaf Mikro Sebagai Solusi Pemberdayaan Ekonomi Masyarakat", Law Reform, 15(2), 177-194, (2019), h. 179

20 Angkat Poenta Pratama, Hari Sutra Disemadi, \& Paramita Prananingtyas. "Existence And Position Of Islamic Economic Laws In Indonesia”, Legality: Jurnal Imiah Hukum, 27(2), 222-231, (2019), h. 223

21 Aziz Budi Setiawan. "Perbankan Syariah; Challenges dan Opportunity Untuk Pengembangan di Indonesia." Jurnal Kordinat, 8(1), 1-42, (2006), h. 21

22 Muslimin Kara. "Konstribusi Pembiayaan Perbankan Syariah Terhadap Pengembangan Usaha Mikro Kecil Dan Menengah (UMKM) Di Kota Makasar," Asy-Syir'ah: Jurnal Ilmu Syariah dan Hukum, 47(1), 269-312, (2013), h. 281-283
} 
Disebutkan di atas muamalah merupakan komponen yang menyangkut kehidupan ekonomi Islam.23 Cukup banyak panduan atau tuntunan Agama Islam yang mengatur kehidupan ekonomi umat khusnay dibidang lembaga keuangan syariah yang antara lain secara garis besar adalah: (1). Tidak memperkenankan adanya unsur spekulasi dan perjudian dalam kegiatan ekonomi yang diyakini akan mendatangkan kerugian bagi masyarakat. Agama Islam menempatkan uang sebagai alat tukar bukan melaikan sebagi komoditi untuk diperdagangkan apalagi mengadung unsur ketidakpastian atau spekulasi (gharar); (2). Harta harus berputar (diniagakan) sehingga tidak boleh hanya berpusat pada segelintir orang sehingga manusia sebagai khalifah yang menerima amanah dari Allah SWT., diharus produktif dan menjadikan hartanya bermamfaat bagi kemakmuran dan kesejahteraan oarang banyak; (3). Bekerja (mencari nafkah) merupakan ibadah dan wajib dilakukan setiap orang artinya setiap manusia harusnya siap menghadapi resiko dari bekerja seperti mendapatkan keuantungan atau mamfaat dibandingkan mamfaat yang hanya mampir tanpa resiko dan keuntungan yang bersifat tetap (bunga deposito); (4). Kegiatan ekonomi Islam harus dilakukan secara transparan dan adil atas dasar suka smasuka tanpa ada paksaan dari pihak manapun; (5). Zakat sebagai intrumen untuk pemenuhan kewajiban penyisihan harta yang juga merupakan hak orang lain.

Berbicara tentang hak asasi maka terlebih dahulu perlu dijelaskan mengenai pengertian dasar hak itu sendiri. Secara fundamental hak merupakan unsur normatif yang berfungsi sebagai pedoman bertingkahlaku, perlindungan akan kebebasan, suatu kekebalan dalam menjamin adanya peluang bagi manusia dalam menjaga harkat dan martabatnya.24 Kemudian terkait Hak Asasi Manusia (HAM), John Locke menyatakan bahwa HAM adalah hak kodrati yaitu hak-hak yang diberikan langsung oleh Sang Pencipta kepada manusia. Hak kodrati merupakan hak yang sifatnya sangat mendasar (fundamental) bagi hidup dan kehidupan yang tidak ada kekuasaan apapun di dunia yang dapat mencabutnya.25 Di Indonesia definisi HAM telah disebutkan dalam Pasal 1 UU No. 39 Tahun 1999 tentang HAM.26 Dapat disimpulkan bahwa HAM merupakan hak yang melekat pada diri manusia yang sifatnya kodrati dan

\footnotetext{
23 Ayup Suran Ningsih \& Hari Sutra Disemadi. "Breach of Contract: An Indonesian Experience in Akad Credit of Sharia Bangking", Ijtihad: Jurnal Wacana Hukum Islam Dan Kemanusiaan, 19(1), 89-102, (2019), h. 89

24 Tim ICC UIN Jakarta. Demokrasi, Hak Asasi Manusia dan Masyarakat Madani, (Jakarta: Preneda Media, 2003), h. 199

25 Masyur Effendi. Dimensi Dan Dinamika Hak Asasi Manusia Dalam Hukum Nasional Dan Internasional, (Jakarta: Ghalia Indonesia, 1994), h. 3

${ }_{26}$ Pasal ini menyebutkan "Hak Asasi Manusia (HAM) adalah seperangkat hak yang melekat pada hakikat dan keberadaan manusia sebagai makhluk Tuhan Yang Maha Esa dan merupakan anugerah-Nya yang wajib dihormati, dijunjung tinggi, dan dilindungi oleh negara, hukum, pemerintah dan setiap orang demi kehormatan serta perlindungan harkat dan martabat manusia".
} 
fundamental sebagai anugerah Tuhan yang harus dijaga, dihormati, dan dilindungi oleh setiap individu, masyarakat, dan negara.

Terkait dengan dalam penyelenggaraan lembaga keuangan di Indonesia, setiap nasabah berhak atas kepastian hukum dalam menjamin perlindungan akan hak-haknya seperti yang disebutkan pada Pasal 1 Ayat (1) UU No. 8 Tahun 1999 tentang Perlindungan Konsumen.27 Perlindungan yang dimaksud mencakup perlindungan umum dan perlindungan khusus. Perlindungan umum merupakan perlindungan materil berupa keselamatan dana nasabah, transparansi informasi, advokasi dan lain sebagainya sedangkan perlindungan khusus merupakan perlindungan spiritual nasabah.28 Perlindungan spiritual dimaksud merupakan salah satu komponen penting dalah kehidupan ekonomi Agama Islam yaitu muamalah.

Berbicara perlindungan spiritual maka dapat dikatakan bahwasanya satiap nasabah memiliki hak spiritual yang perlu dilindungi. Hak spiritual adalah hak keagamaan yang dimiliki oleh setiap manusia. Khususnya di Indonesia yang hak spiritual lebih identik dengan hak umat muslim, dikarenakan mayoritas jumlah penduduk Indonesia adalah beragama Islam. Perspeketif perlindungan konsumen, Ro'fah Setyowati menyebutkan bahwasanya konsumen lembaga keuangan Islam memiliki hak spiritual atau hak keagamaan, di Indonesia hak tersebut dijamin atau dilindungi melalui bentuk prinsip syariah dalam penyelenggaraan lembaga keuangan berbasis syariah.29 Pemikiran ini timbul atas aspek spiritual yang melekat pada setiap diri seseorang terutama pada diri konsumen.30

Perlunya menjalani kehidupan ekonomi yang baik berdasarkan prinsip-prinsip syariah ini perlu didukung dan perhatian oleh pemerintah, masyarakat ataupun perkumpulan masyarakat. Implementasi dukungan tersebut dapat melalui peraturan-peraturan, dan peran aktif terkait hak spiritual masyarakat. Seperti telah disebutkan di atas dalam perspektif perlindungan konsumen, penerapan prinsip-prinsip syariah pada lembaga keuangan Islam adalah bentuk jaminan perlindungan hak spiritual. Sifat spiritual itu sendiri telah dijelaskan dalam prinsip-prinsip perlindungan konsumen dalam UU Perlindungan Konsumen. Selain itu,

\footnotetext{
27 Pasal ini menyebutkan "Perlindungan konsumen adalah segala upaya yang menjamin adanya kepastian hukum untuk memberikan perlindungan kepada nasabah".

28 Ro'fah Setyowati. Bahan Ajar Hukum Ekonomi Syariah, Semarang: Prodi Magister Ilmu Hukum Universitas Diponegoro, 2019

29 Ro'fah Setyowati. Bahan Ajar Hukum Ekonomi Syariah, Semarang: Prodi Magister Ilmu Hukum Universitas Diponegoro, 2019

30 Ro'fah Setyowati. “Consumers Spiritual Rigths In The Islamic Bangking Dispute Out Of Court Settlement In Indonesia.” Journal Of Social Studies Education Research, 9(4), 334-351, (2018), h. 334
} 
kepatuhan terhadap prinsip-prinsip syariah dalam lembaga keuangan Islam juga telah diatur dalam berbagai peraturan perundang-undangan terkait bidangnya masing-masing.31

Telah disebutkan bahwa BWM merupakan LKM yang penyelenggaraannya kegiatan usahanya berdasarkan prinsip syariah yang telah disebutkan dalam pasal 12 Ayat (2) UU LKM.32 Selain itu pengaturan penerapan prinsip syariah dalam penyelenggaraan BWM juga disebutkan pada Pasal 2 POJK No. 62/POJK.05/2015.33 BWM wajib menggunakan akad penyaluran pembiayaan yang sesuai dengan prinsip syariah yaitu akad yang telah ditetapkan oleh fatwa DSN-MUI.

Ditinjau dari Hukum Islam, perjanjian yang disebut juga dengan akad merupakan perbuatan yang dibuat oleh dua orang atau lebih dengan persetujuan masing-masing. Dengan kata lain akad adalah perikatan yang secara sengaja dilakukan antara ijab34dan qabul35 yang dibenarkan secara syariah.36Ahmad Azhar Basyir Basyir mendefinisikan akad sebagai perikatan antara ijab dan Kabul dengan cara yang telah dibenarkan oleh syara' yang menetapkan akibat-akibat hukum.37Pasal 13 Ayat (2) POJK No. 62/POJK.05/2015 menyebutkan "kegiatan usaha penyaluran pembiayaan dilakukan dengan dengan menggunakan akad mudharabah, musyarakah, murabahah, ijarah, salam, istishna, ijarah muntahin bit tamlik, atau akad lain yang tidak bertentangan dengan prinsip syariah serta disetujui oleh OJK".

Ketentuan pembiayaan mudharabah diatur dalam Fatwa DSN No:07/DSNMUI/IV/2000 tentang Pembiayaan Mudharabah (Qiradh), namun tidak menyebutkan definisi akad mudharabah melainkan menyebutkan definisi pembiayaan mudharabah. "Pembiayaan mudharabah adalah pembiayaan yang disalurkan oleh Lembaga Keuangan Syariah kepada pihak lain untuk suatu usaha yang produktif'. Ketentuan definisi akad mudharabah diatur lebih lanjut dalam Fatwa DSN-MUI No:115/DSN-MUI/IX/2017 Tentang Akad Mudharabah.

\footnotetext{
31 Ro'fah Setyowati. Loc.Cit.,h.

32 Pasal ini menyebutkan "Penyaluran pinjaman atau pembiayaan dan pengelolaan simpanan oleh LKM sebagaimana dimaksud dalam Pasal 11 Ayat (1) dilaksanakan secara konvensional dan berdasarkan prinsip syariah".

33 Pasal ini menyebutkan "Kegiatan usaha sebagaimana dimaksud pada ayat (1) dapat dilakukan secara konvensional atau berdasarkan prinsip syariah".

34Ijab didefinisikan oleh Ahmad Azhar Basyir sebagai "pernyataan pihak pertama mengenai isi perikatan yang di inginkan" dalam Ahmad Azhar Basyir. Azas-Azas Hukum Muamalah. (Yogyakarta: UII Press, 2014), h. 34

${ }_{35}$ Kabul didefinisikan oleh Ahmad Azhar Basyir sebagai "pernyataan pihak kedua untuk merima pernyataan pihak pertama mengenai isis perikatan" dalam Ahmad Azhar Basyir. Loc.Cit.

36 Wardah Yuspin. "Penerapan Prinsip Syariah Dalam Pelaksanaan Akad Murabahah.” 10(1), 55-67, (2007), h. 58

37 Ahmad Azhar Basyir. Op.Cit., h. 34
} 
Dalam fatwa ini menyebutkan "akad mudharabah adalah akad kerja sama usaha antara pemilik modal (malik / shahib al-mal) yang menyediakan seluruh modal dengan pengelola ('amil / mudharib) dan keuntungan seluruh usaha dibagi di antara mereka sesuai nisbah yang disepakati dalam akad".

Ketentuan pembiayaan musyarakah diatur dalam fatwa DSN No:08/DSN-MUI/IV/2000 Tentang Pembiayaan Musyarakah, namun di dalam fatwa ini tidak menyebutkan definisi mengenai akad musyarakah. Definisi akad musyarakah diatur lebih lanjut di dalam Fatwa DSN-MUI No:105/DSN-MUI/X/2016 Tentang Penjaminan Pengembalian Modal Pembiayaan Mudharabah, Musyarakah dan Wakalah Bil Istitsmar. Fatwa DSN-MUI No:105/DSNMUI/X/2016 mendefinisikan "akad musyarakah adalah pembiayaan berdasarkan akad kerjasama antara 2 pihak atau lebih untuk suatu usaha tertentu, dimana masing-masing pihak memberikan kontribusi modal dengan ketentuan bahwa keuntungan dibagi sesuai nisbah yang disepakati dan kerugian akan ditanggung bersama secara proporsional”.

Ketentuan murabahah diatur dalam Fatwa DSN No:04/DSN-MUI/IV/2000 Tentang Murabahah, fatwa ini tidak menyebutkan definisi akad murabahah secara gamblang, namun disebutkan di dalam Fatwa DSN-MUI No:84/DSN-MUI/XII/2012 Tentang Metode Pengakuan Keuntungan AL-Tamwil bi Al-Murabahah (Pembiayaan Murabahah) Di Lembaga Keuangan Syariah. Fatwa ini menyebutkan“murabahah adalah akad jual beli dengan menegaskan harga belinya kepada pembeli dan pembeli membayarnya dengan harga yang lebih sebagai keuntungan sedangkan pembiayaan murabahah (At-Tamwil bi al-Murabahah) adalah murabahah di Lembaga Keuangan Syariah (LKS) dengan cara LKS membelikan barang sesuai dengan pesanan nasabah, kemudian LKS menjualnya kepada nasabah (setelah barang menjadi milik LKS) dengan pembayaran angsuran”. Akad jual beli murabahah ini juga ditegaskan kembali dalam Fatwa DSN-MUI No:111/DSN-MUI/IX/2017 Tentang Akad Jual Beli Murabahah, yang mana “akad bai' al-murabahah adalah akad jual beli suatu barang dengan menegaskan harga belinya kepada pembeli dan pembeli membayarnya dengan harga yang lebih sebagai laba".

Ketentuan mengenai pembiayaan ijarah diatur dalam Fatwa DSN No:09/DSNMUI/IV/2000 Tentang Pembiayaan Ijarah. Fatwa ini tidak menyebutkan definisi akad ijarah secara jelas, namun definisi akad ijarah disebutkan dalam Fatwa DSN-MUI No:112/DSNMUI/IX/2017 Tentang Akad Ijarah. Fatwa ini disebutkan "akad ijarah adalah akad sewa 
antara mu'jir (pemberi sewa)dengan musta'jir (penyewa) atau antara musta'jir dengan ajir (pemberi jasa dalam akad) untuk menpertukarkan manfa'ah dan ujrah, baik mamfaat barang maupun jasa".

Ketentuan akad salam diatur dalam Fatwa DSN No:05/DSN-MUI/IV/2000 Tentang Jual Beli Salam. Fatwa ini menyebutkan "salammerupakan jual beli barang dengan cara pemesanan dan pembayaran harga lebih dahulu dengan syarat-syarat tertentu". Fatwa tentang Jual Beli Salam menetapkan ketentuan tentang pembayaran, tentang barang, salam parallel, penyerahan barang sebelum atau pada waktunya, pembatalan kontrak dan ketentuan perselisihan.

Ketentuan akad istishna' diatur dalam Fatwa DSN No:06/DSN-MUI/IV/2000 Tentang Jual Beli Istishna'. Dalam fatwa ini menyebutkan 'akad istishna' adalah akad jual beli dalam bentuk pemesanan pembuatan barang tertentu dengan kriteria dan persyaratan tertentu yang disepakati antara pemesan (pembeli, mustashni') dan penjual (pembuat, shani')”. Sesuai perkembangannya akad istishna' berkembang menjadi akad istishna' parallel dimana LKS dalam memenuhi kewajibannya terhadap nasabah membutuhkan pihak lain sebagai shani'. Ketentuan jual beli akad istishna' paralel diatur dalam Fatwa DSN No: 22/DSNMUI/III/2002 Tentang Jual Beli Istishna' Paralel.

Akad ijarah muntahiah bit tamlik merupakan akad baru yang dibuat oleh Lembaga Keungan Syariah dengan nasabah (ex-murabahah). Pengaturan akad ini disebutkan di dalam Fatwa DSN No:49/DSN-MUI/II/2005 Tentang Konversi Akad Murabahah. Akad baru ini di dalam Fatwa No:49/DSN-MUI/II/2005 dapat dibuat "apabila nasabah mengalami penurunan kemampuan dalam pembayaran cicilan, maka ia diberikan keringanan, diwujudkan dalam bentuk konversi dengan membuat akad baru dalam penyelesaian pembayaran kewajiban merujuk Fatwa DSN No: 27/DSN-MUI/III/2002 Tentang Al Ijarah Al-Muntahiah Bi AlTamlik".

Ketentuan akad-akad yang telah dijelaskan di atas merupakan salah satu bentuk pengaturan yang jelas terkait penjaminan perlindungan hak spiritual dari penerapan tata kelola BWM sebagai lembaga keuangan syariah. Ketentuan tentang penggunaan akad/perjanjian berdasarkan Fatwa DSN-MUI merupakan bentuk pemenuhan prinsip-prinsip syariah dalam penyelenggaraan BWM. Perhatian terhadap perlindungan hak spiritual sangat diperlukan untuk membangun LKM bersbasis Islam khususnya BWM ini memiliki kredibilitas tinggi, sehingganya menurunkan ataupun meruntuhkan sikap skeptis dari masyarakat terkait lembaga 
keuangan syariah di Indonesia.38 Kredibilitas yang tinggi ini juga dimaksudkan untuk mendapatkan kepercayaan publik bahwasanya BWM menjunjung tinggi prinsip-prinsip syariah.

\section{KESIMPULAN}

Penyelenggaraan Bank Wakaf Mikro (BWM) merupakan implemntasi dari amanat Undang-Undang Dasar 1945 dalam mensejahterakan masyarakat Indonesia. Kebijakan pengaturan penyelenggaran BWM di Indonesia diatur dalam UU Lembaga Keuangan Mikro, POJK tentang Penyelenggaraan Usaha Lembaga Keuangan Mikro. BWM merupakan salah satu lembaga keuangan mikro yang menerapkan Hukum Islam atau prinsip syariah yang ditujukan untuk memberikan pembiayaan demi mengurangi ketimpangan kemiskinan masyarakat. Pendirian BWM dimaksudkan dapat terus berkontribusi dalam memberdayakan anggota dan masyarakat berpenghasilan rendah sebagai pelaku usaha mikro.

Perspektif perlindungan konsumen, terdapat dua jenis hak nasabah atau masyarakat yang harus dilindungi yaitu hak materil dan hak spiritual. Hak spiritual merupakan hak terkait rahasia nasabah, dana nasabah dan advokasi terhadap nasabah. Sedangkan hak spiritual merupakan hak keagamaan yang patut dilindungi terkait kebebasan masyarakat untuk menjalankan kegiatan ekonomi sesuai Agamanya. Penyelenggaraan BWM dalam melindungi hak spiritual nasabah adalah dengan menerapkan akad-akad pembiayaan yang telah diatur sesuai ketentuan yang berlaku dan sesuai Fatwa DSN-MUI.

\section{REFERENCES}

Ali, Z. (2018). Metode Penelitian Hukum, Jakarta: Sinar Grafika.

Basyir, A.A. (2014).Azas-Azas Hukum Muamalah, Yogyakarta: UII Press.

Disemadi, H.S.\& Roisah, K. (2019). “Kebijakan Model Bisnis Bank Wakaf Mikro Sebagai Solusi Pemberdayaan Ekonomi Masyarakat", Law Reform, 15(2), 177-194.

Disemadi, H.S.,\& Santoso, B. (2019). "Pelaksanaan Fungsi Pembinaan Dan Pengawasan Otoritas Jasa Keuangan Terhadap Lembaga Keuangan Mikro Syariah Di Jawa Tengah (Studi Pada Bank Wakaf Mikro Sunan Gunung Jati Ba'alwy)", Tesis: Fakultas Hukum Universitas Diponegoro.

38 Ro'fah Setyowati, Lastuti Abubakar \& Nunung Rodliah. "Sharia Governance On Islamic Banking: Spiritual Rights Perspective On Consumer Protection In Indonesia.” Diponegoro Law Review, 2(1), 227-244, (2017), h. 227 
Effendi, M. (1994).Dimensi Dan Dinamika Hak Asasi Manusia Dalam Hukum Nasional Dan Internasional, Jakarta: Ghalia Indonesia.

Disemadi, H.S.,\& Wahyuni, R.A.E. (2019). "Eksistensi Dan Kebijakan Regulasi Perizinan Lembaga Keuangan Mikro Oleh Otoritas Jasa Keuangan”, Yustisiabel, 3(2), 106-117.

Kara, M. (2013). "Konstribusi Pembiayaan Perbankan Syariah Terhadap Pengembangan Usaha Mikro Kecil Dan Menengah (UMKM) Di Kota Makasar," Asy-Syir'ah: Jurnal Ilmu Syariah dan Hukum, 47(1), 269-312.

Mu'allim, A. (2003). "Persepsi Masyarakat terhadap Lembaga Keuangan Syariah.” AlMawarid Journal of Islamic Law, Edisi 10, 17-31.

Mustaqim, M. (2016). "Prinsip Syariah Dalam Manajemen Sumber Daya Manusia (Studi Atas Implementasi Manajemen Sumber Daya Manusia UMKM di Kudus)." Jurnal Penelitian, 10(2), 399-422.

Ningsih, A.S.,\& Disemadi, H.S. (2019). "Breach of Contract: An Indonesian Experience in Akad Credit of Sharia Bangking", Ijtihad: Jurnal Wacana Hukum Islam Dan Kemanusiaan, 19(1), 89-102.

Pratama, A.P., Disemadi, H.S.,\& Prananingtyas, P. (2019). "Existence And Position Of Islamic Economic Laws In Indonesia”, Legality: Jurnal Imiah Hukum, 27(2), 222-231.

Setiawan, A.B. (2006). "Perbankan Syariah; Challenges dan Opportunity Untuk Pengembangan di Indonesia." Jurnal Kordinat, 8(1), 1-42.

Setyowati, R. (2018). "Consumers Spiritual Rigths in the Islamic Bangking Dispute Out Of Court Settlement in Indonesia." Journal of Social Studies Education Research, 9(4), 334-351.

Setyowati, R., Abubakar, L.,\& Rodliah, N. (2017). "Sharia Governance on Islamic Banking: Spiritual Rights Perspective on Consumer Protection in Indonesia." Diponegoro Law Review, 2(1), 227-244.

Soemitra, A. (2018).Bank Dan Lembaga Keuangan Syariah, Jakarta: Prenadamedia Group.

Suteki \& Taufani, G. (2018)Metodologi Penelitian Hukum (Filsafat, Teori Dan Praktik), Depok: PT RajaGrafindo Persada.

Tim ICC UIN Jakarta. (2003).Demokrasi, Hak Asasi Manusia dan Masyarakat Madani, Jakarta: Preneda Media.

Yuspin, W. (2007) "Penerapan Prinsip Syariah dalam Pelaksanaan Akad Murabahah." Publikasi Ilmiah, 10(1), 55-67.

Website:

Otoritas Jasa Keuangan, Mewujudkan Kesejahteraan Masyarakat Dengan Bank Wakaf Mikro. Retrived from www.sikapiuangmu.ojk.go.id Diakses Pada Tanggal 15 September 2019.

Otoritas Jasa Keuangan, Siaran Pers OJK Keluarkan Izin 41 Bank Wakaf Mikro, Retrived fromwww.ojk.go.id. Diakases Pada Tanggal 2 September 2019. 